\title{
Water quality evaluation of Himalayan Rivers of Kumaun region, Uttarakhand, India
}

\author{
Richa Seth • Manindra Mohan • Prashant Singh • \\ Rakesh Singh $\cdot$ Rajendra Dobhal $\cdot$ Krishna Pal Singh • \\ Sanjay Gupta
}

Received: 22 January 2014/ Accepted: 10 June 2014/Published online: 17 June 2014

(C) The Author(s) 2014. This article is published with open access at Springerlink.com

\begin{abstract}
Water quality of Himalayan rivers has been steadily deteriorating over several decades due to anthropogenic activities, dumping of treated or untreated effluents, poor structured sewerage and drainage system, etc. In the present study, the water quality of five important rivers namely, Gola, Kosi, Ramganga, Saryu and Lohawati rivers were investigated which flow through the different districts of Kumaun region of Uttarakhand Himalaya. The water of all these rivers serves as the major source for drinking and irrigation purposes in these districts of the Kumaun region of Uttarakhand. River water samples collected in premonsoon and post-monsoon seasons of the years 2011 and 2012 were analyzed for various water quality characteristics. Statistical analyses indicate positive correlation among most of the chemical parameters. Piper diagram illustrates that all the water samples fall in $\mathrm{Ca}-\mathrm{Mg}-\mathrm{HCO}_{3}$ hydrochemical facies, Moreover, the suitability of water
\end{abstract}

R. Seth · M. Mohan · P. Singh ( $₫)$

Department of Chemistry, DAV (PG) College,

Dehradun 248001, Uttarakhand, India

e-mail: prashant.ucost@gmail.com

\section{R. Singh}

Department of Chemistry, DBS (PG) College, Dehradun 248001,

Uttarakhand, India

R. Dobhal

National Research Development Corporation (NRDC),

New Delhi 110048, India

\section{K. P. Singh}

Biophysics and Nanotechnology Research Laboratory, CBSH, GBPUAT, Pantnagar 263145, Uttarakhand, India

\section{S. Gupta}

Department of Biotechnology and Biochemistry, SBSPGI, Balawala, Dehradun 248161, Uttarakhand, India for drinking purposes determined by water quality index indicated that river water in both the seasons is unsuitable. Irrigation water quality of all the river water was found suitable during both the seasons according to the result of sodium adsorption ratio, sodium percentage and residual sodium carbonate. The present study revealed that major factors contributing to deterioration of water quality of all the rivers might be eutrophication, tourism, anthropogenic and geogenic processes. Therefore, to restore the vitality and water quality of all these rivers, proper water resource planning programme should be developed.

Keywords Himalayan Rivers - Seasonal variation ·

Correlation · Water quality index · Irrigation water quality

\section{Introduction}

River is an important resource of surface water for domestic and irrigation purposes. Currently, the quality of river water is a matter of serious concern due to rapid increase in the population, urbanization, industrialization and deforestation. The available river water resources are getting depleted and being adversely affected both qualitatively and quantitatively (Sati and Paliwal 2008; Desai and Tank 2010; Shrivastava et al. 2013). River water quality is highly variable, which depends not only with regards to their spatial distribution but also over time. Assessment of seasonal changes in surface water quality is an important aspect for evaluating temporal variation of river pollution due to natural or anthropogenic inputs of point and nonpoint sources (Baig et al. 2010; Bu et al. 2010; Rani et al. 2011; Shetty et al. 2013).

Uttarakhand, a Himalayan state of India, is comprised of Garhwal and Kumaun regions. Being hill state, the 
geographical conditions are totally different from the other plain states of India. This state has origin of many holy rivers and springs, which play important roles in Indian culture and tradition (Semwal and Akolkar 2006). The Kumaun division lies between $28^{\circ} 44^{\prime}$ and $30^{\circ} 49^{\prime} \mathrm{N}$ latitudes and $78^{\circ} 45^{\prime}$ and $81^{\circ} 05^{\prime} \mathrm{E}$ longitude and the main sources of water in Kumaun division are rivers, streams (of all sizes), springs and lakes. These serve as sources of water and more than $50 \%$ of total populations of the region meet their daily requirement through them (Singh and Rawat 1985). The local peoples use several traditional water management techniques to store their drinking and irrigation water (Rawat and Sah 2009). But nowadays, water of these rivers is being polluted by different means such as domestic waste, weathering of rocks, anthropogenic activities, and sewage effluents, etc., which affect the physico-chemical and biological properties of water, which are directly related to the water quality of rivers (Alam et al. 2007a, b; Chandra et al. 2006; Sharma and Kansal 2011). Due to high load of contamination, rivers have become unable to rejuvenate them and with continued pollution, self purification capability of rivers is diminishing and their water is becoming unfit for drinking, agricultural as well as other domestic purposes. Therefore, the water quality evaluation of rivers and their proper maintenance become necessary for the safety of human beings.

Some investigations on water quality assessment of different rivers of Uttarakhand (Sati and Paliwal 2008; Paliwal and Sati 2009; Semwal and Jangwan 2009; CPCB 2010; Bhandari and Joshi 2013) have been reported. However, literature survey also revealed that so far little work has been carried out on the water quality of Himalayan rivers of Kumaun. Thus, in continuation of our previous work (Gupta et al. 2012a, b; Sharma et al. 2012; Seth et al. 2013a, b, 2014; Tyagi et al. 2013), the aim of the present study is to investigate the drinking and irrigation water quality status of five major rivers of Kumaun division of Uttarakhand namely, Gola, Ramganga, Saryu, Kosi and Lohawati Rivers belonging to five districts of Kumaun division of Nainital, Pithoragarh, Bageshwar, Almora and Champawat districts, respectively. Thus, the aim of the present study is to evaluate status of water quality of identified five rivers of Kumaun division of Uttarakhand, India.

\section{Materials and methods}

Studied rivers

Water quality of five rivers of Kumaun division of Uttarakhand, which are prominent for different drinking, domestic and irrigation activities was assessed for different drinking and irrigation water quality parameters during pre-monsoon (PRM) and post-monsoon (POM) seasons of the years 2011 and 2012. In this respect, the concise of the studied rivers is summarized below:

\section{Gola River}

Gola River originates from Lesser Himalayas majorly a spring fed river. This river is a source of water for Haldwani and Kathgodam town. A very beautiful dam exists over this river in Kathgodam. This river has been into controversies also due to illegal mining. The steady erosion of the Gola River forest corridor threatens the survival of tigers, elephants and others wild animals in this Terai region of Kumaun.

\section{Ramganga River}

Ramganga originates from the Namik Glacier located between Birthi fall and Kwiti village in Pithoragarh district of Kumaun division of Uttarakhand and flows towards east through a number of dense forest areas. This river is fed by numerous small and big rivers and finally joins Saryu River at Rameshwar near Ghat of Pithoragarh.

\section{Saryu River}

Saryu the holy river of Uttarakhand emerges from the Himalayas and merges with Yamuna in Ayodhya, the birth place of Lord Rama. This river is of ancient significance, finding mentions in the Vedas and Ramayana. On Ram Navami, the 9 day festival that celebrates the birthday of Lord Rama, dipping in the Saryu River at Ayodhya by thousands of people takes place.

\section{Kosi River}

Kosi River is a major tributary of the holy River Ganga which originates from spring source at Rudradhari (district Almora, Kumaun division, Uttarakhand) with total catchment area as $3,420 \mathrm{sq} \mathrm{km}$. Total length of river is $240 \mathrm{~km}$. It is being used for various purposes such as drinking, washing and bathing, fishing, waste dumping like solid waste, domestic waste, industrial waste, cremation waste, etc.

\section{Lohawati River}

Lohawati River originates near the majestic Vanasur Ka Kila, situated $7 \mathrm{~km}$ from Lohaghat and $20 \mathrm{~km}$ from district Champawat of Kumaun division of Uttarakhand. Lohaghat town situated on the bank of this river has a historical and 
mythological importance. The Lohawati River is the lifeline for the several villagers of different areas of Uttarakhand. The water of this river is not only used for drinking purpose but also for irrigation especially for seasonal vegetables and hydroelectric purposes for the state.

\section{Sample collection procedure}

The water samples were collected from all five rivers during PRM and POM seasons in the years 2011-2012 during the month of April-June and October-December, respectively. The samples were collected from different sites of all the rivers. The detail of sampling sites is shown in Fig. 1.

\section{Analytical methods}

The physico-chemical parameters like $\mathrm{pH}$, alkalinity, and turbidity were analyzed onsite. The other parameters such as hardness, total dissolved solids (TDS), nitrate, chloride, fluoride, sulphate, sodium, potassium, calcium, magnesium, iron and total coliform (TC) and faecal coliform (FC) were analyzed in laboratory after samples preservation as per Bureau of Indian Standards (BIS 1991) and American Public Health Association (APHA) (Eaton et al. 2005) guidelines.

$\mathrm{pH}$ and turbidity were measured using $\mathrm{pH}$ metre (PC-II, Hach, USA) and Nephelometer (Model: PC compact; Make: Aqualytic, Germany), respectively. The colorimetric analyses such as sulphate, fluoride, and nitrate were measured using DR 5000 Spectrophotometer (Hach, USA). The metal ions analyses were performed on Varian-AA240 Atomic Absorption Spectrophotometer (AAS). For microbial analysis, the membrane filter technique was used to determine the number of colonies/100 $\mathrm{ml}$ of the sampled water.

The statistical analysis was carried out using SPSS 13 to identify the correlation between selected water quality parameters. Piper diagrams were developed using AquaChem software version 2011.1 to have conclusive information about hydrogeochemical facies of all the rivers. Water quality index (WQI) of all the rivers have been calculated to find its suitability for drinking purposes by Weight Arithmetic WQI using 11 water quality parameters. Parameters such as sodium adsorption ratio (SAR), sodium percentage $(\mathrm{Na} \%)$ and residual sodium carbonate (RSC)

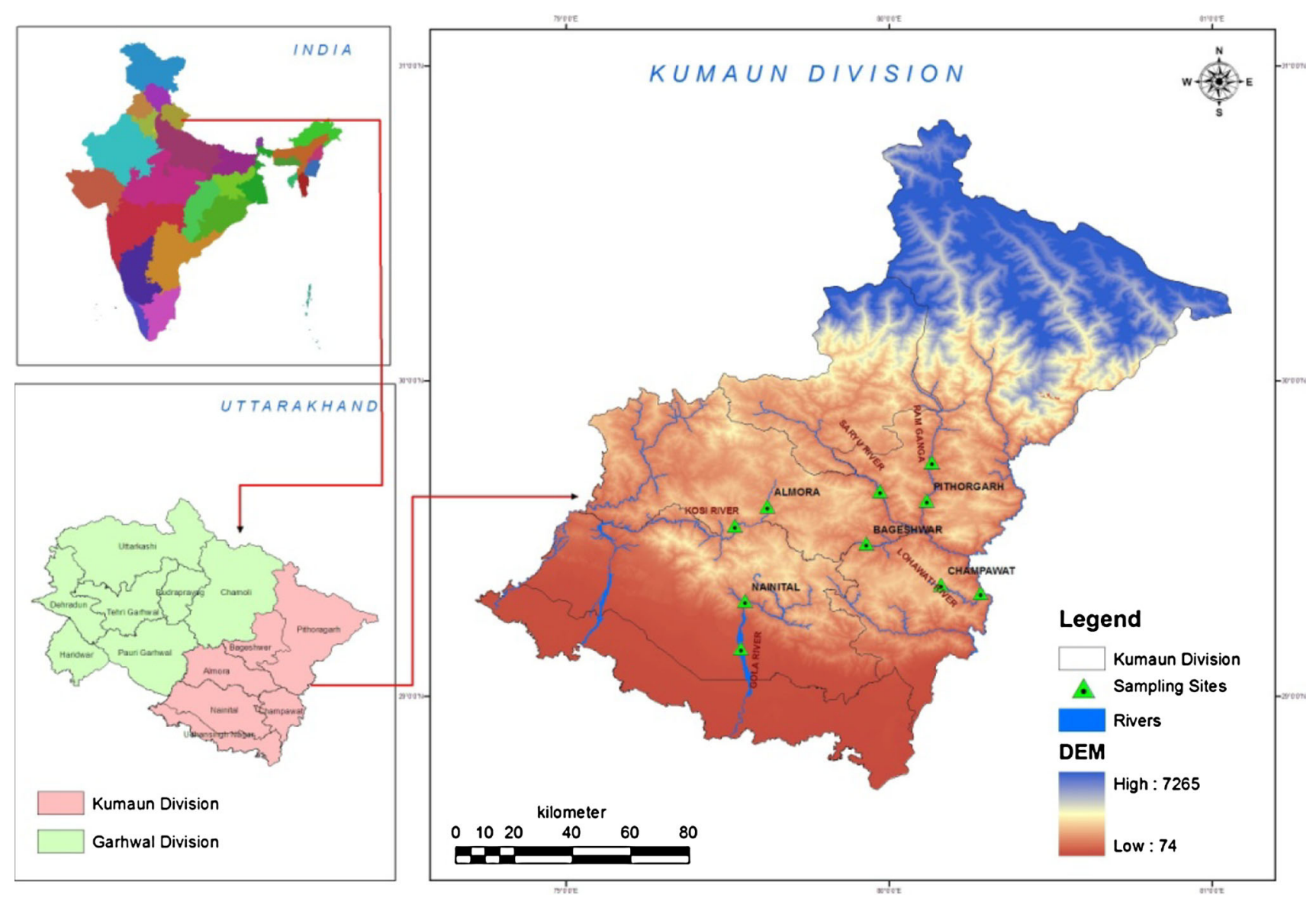

Fig. 1 Location map of sampling sites of studied five rivers of Kumaun region of Utttarakhand (India) 
were determined to assess the suitability of river water for irrigation purposes.

\section{Results and discussion}

The analyzed results of water quality parameters in PRM and POM seasons of 2011 and 2012 of five rivers of Kumaun region of Uttarakhand Himalaya are presented in Table 1.

Turbidity measures the water clarity and is due to suspended solid materials such as clay, silt, colloidal organic matter, planktons, and other organisms (Dorner et al. 2007). The turbidity average values varied from $5.4 \pm 1.08$ to $14.3 \pm 3.10$ and from $7.4 \pm 1.61$ to $47.3 \pm 8.12 \mathrm{NTU}$ during PRM and POM seasons, respectively. All the samples were found above desirable limit of 5 NTU and permissible limit of 10 NTU. Consumption of turbid water causes gastroenteritis problem (Morris et al. 1996). $\mathrm{pH}$ generally indicates the nature of water quality as acidic or alkaline. In the study, $\mathrm{pH}$ values of all the river water samples have $\mathrm{pH}$ within BIS prescribed limit of 6.5-8.5. $\mathrm{pH}$ average value in the analyzed water samples ranged from $7.66 \pm 0.27$ to $8.48 \pm 0.14$ in PRM season and from $7.61 \pm 0.22$ to $8.12 \pm 0.34$ in POM season. Higher values of $\mathrm{pH}$ cause bitter taste to water, affect mucous membrane, cause corrosion and also affect aquatic life (Narasimha Rao et al. 2011).

Hardness is the property of water which prevents lather formation with soap. Principal cations imparting hardness are calcium and magnesium. However, other cations such as strontium, iron and manganese also contribute to hardness. The anions responsible for hardness are mainly bicarbonate and carbonate. The hardness mean concentration in river water samples ranged from $342 \pm 19.69$ to $570 \pm 86.16 \mathrm{mg} / \mathrm{l}$ in PRM and from $70 \pm 23.18$ to $206 \pm 35.77 \mathrm{mg} / \mathrm{l}$ in POM season. The concentration during PRM season of all the river water samples exceeded the desirable limit of hardness i.e. $300 \mathrm{mg} / \mathrm{l}$ but none of the sample in POM exceeded the limit. Water hardness has no adverse effect on health as such but the higher concentration of hardness in water causes heart disease as well as kidney stone problem (Napacho and Manyele 2010). The mean concentration of alkalinity in water ranged from $218 \pm 7.60$ to $461 \pm 12.57$ and from $57 \pm 10.13$ to $186 \pm 34.7 \mathrm{mg} / \mathrm{l}$ during PRM and POM seasons, respectively. The concentration during PRM seasons of all the river water samples exceeded the desirable limit of alkalinity i.e. $200 \mathrm{mg} / \mathrm{l}$ but in POM season concentration is found well within the limit. Alkalinity in water is due to the presence of carbonates, bicarbonates and hydroxide constituents, which may be derived from dissolved rocks, salts or sediments (Kumar et al. 2012).

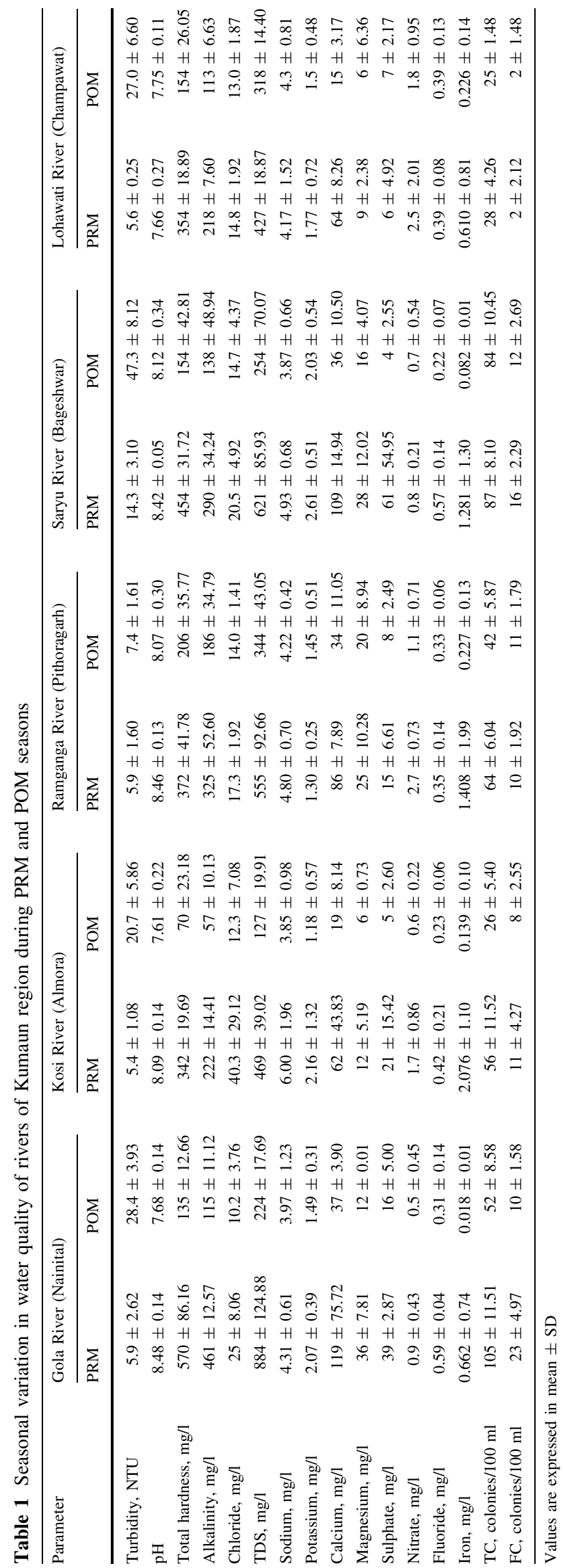


TDS is a direct measure of all the dissolved particles, both organic and inorganic in water. As per BIS, the desirable limit for TDS is $500 \mathrm{mg} / \mathrm{l}$ and permissible limit is $2,000 \mathrm{mg} / \mathrm{l}$. The average value of TDS in PRM season ranged from $427 \pm 18.87$ to $884 \pm 124.88 \mathrm{mg} / \mathrm{l}$ and in POM season varied from $127 \pm 19.91$ to $344 \pm 43.05 \mathrm{mg} / \mathrm{l}$ water samples. TDS mean value in Gola, Ramganga and Saryu River water sample during PRM season recorded more than the desirable limit i.e. $500 \mathrm{mg} / \mathrm{l}$ while in POM seasons none of samples exceeded the limit. High TDS influence the other qualities of water such as taste, hardness, corrosion properties, influences osmoregulation of fresh water organism, and they are not generally removed by conventional method and finally reduce utility of water for drinking and irrigation purposes.

Chloride concentration during the study of all the river water is found quite low. The average concentration in PRM season fluctuated from $14.8 \pm 1.92$ to $40.3 \pm 29.12 \mathrm{mg} / \mathrm{l}$ and in POM from $10.2 \pm 3.76$ to $14.7 \pm 4.37 \mathrm{mg} / \mathrm{l}$. Chloride contents in the water is due to weathering and dissolution of salt deposits, seawater intrusion and irrigation runoff. Excess chloride concentration gives salty taste to water and may result in hypertension, osteoporosis, renal stones, and asthma (McCarthy 2004). Fluoride concentration of approximately $1.0 \mathrm{mg} / \mathrm{l}$ in drinking water effectively reduces dental caries without harmful effects on health but high concentration causes dental and skeletal fluorosis (Fordyce et al. 2007). Fluoride content in river water is also quite low and average value varied from $0.35 \pm 0.14$ to $0.59 \pm 0.04 \mathrm{mg} / \mathrm{l}$ in PRM and from $0.22 \pm 0.07$ to $0.39 \pm 0.13 \mathrm{mg} / \mathrm{l}$ in POM season.

Sulphate occurs naturally in water as a result from gypsum and other common minerals sources. The water samples of all the rivers have sulphate concentration within desirable limit of $200 \mathrm{mg} / \mathrm{l}$ and permissible limit of $400 \mathrm{mg} / \mathrm{l}$ as per BIS. The mean concentration varied from $6 \pm 4.92$ to $61 \pm 54.95$ and from $4 \pm 2.55$ to $16 \pm 5.00 \mathrm{mg} / \mathrm{l}$ during PRM and POM seasons. Sulphate is generally non-toxic but consumption of water with high amount of sulphate causes intestinal problems in normal humans (Heizer et al. 1997). Nitrate occurs naturally and due to its solubility and anionic form, its mobility in groundwater is very high and hence it is very essential to analyze the nitrate in water due its well known adverse effects on health (Nas and Ali 2006). The prescribed limit of nitrate concentration in drinking water recommended by BIS is $45 \mathrm{mg} / \mathrm{l}$. The excess of nitrate causes 'Blue-Baby' disease in bottle-fed infant (Knobeloch et al. 2000). The average concentration of nitrate in all the river water samples was quite low and values fluctuated from $0.8 \pm 0.21$ to $2.7 \pm 0.73$ and from $0.5 \pm 0.45$ to $1.8 \pm 0.95 \mathrm{mg} / \mathrm{l}$ in PRM and POM seasons, respectively.
Calcium is one of the most abundant substances in natural water and occurs from leaching of calcium rich mineral rocks such as lime stone or mineralization of organic matter by bacteria. Therefore, $\mathrm{Ca}$ in natural water differs according to difference in geographic regions or anthropogenic impact. The quantity of $\mathrm{Ca}$ in natural water generally varies from 10 to $100 \mathrm{mg} / \mathrm{l}$ depending on the type of rocks (Trivedy and Goel 1986). Magnesium occurs in all kinds of natural water with calcium, but the concentration remains generally lower than that of calcium. The mean values of calcium and magnesium in water ranged from $62 \pm 43.83$ to $119 \pm 75.72$ and from $9 \pm 2.38$ to $36 \pm 7.81 \mathrm{mg} / \mathrm{l}$ in PRM and from $15 \pm 3.17$ to $37 \pm 3.90$ and from $6 \pm 0.73$ to $20 \pm 8.94 \mathrm{mg} / \mathrm{l}$ in POM season. Concentration of calcium in water samples of Gola, Ramganga and Saryu River in PRM season exceeded the desirable limit i.e. $75 \mathrm{mg} / \mathrm{l}$, while magnesium concentration only exceeded in Gola River from the desirable limit i.e. $30 \mathrm{mg} / \mathrm{l}$. In POM season none of samples recorded the values of calcium and magnesium more than the desirable limit. The concentration of sodium in all the river water samples were low and found within the prescribed limit of $20 \mathrm{mg} / \mathrm{l}$ (WHO 2003) while BIS has not prescribed the limit for sodium. The average mean of sodium varied from $4.17 \pm 1.52$ to $6.00 \pm 1.96$ and from $3.85 \pm 0.98$ to $4.32 \pm 0.81 \mathrm{mg} / \mathrm{l}$ in PRM and POM seasons, respectively. The potassium average concentration was also found in very low amount and varied in PRM and POM seasons from $1.30 \pm 0.25$ to $2.61 \pm 0.51$ and from $1.18 \pm 0.57$ to $2.03 \pm 0.54 \mathrm{mg} / \mathrm{l}$, respectively. No standard limit has been suggested for potassium by WHO and BIS.

Iron contamination in water is due to weathering of rocks and industrial waste, etc. Consumption of drinking water with high level of iron may cause liver disease called 'Haemosiderosis' (Rajappa et al. 2010). During the analysis, the iron average concentration in all river water samples varied from $0.610 \pm 0.81$ to $2.076 \pm 1.10$ during PRM season and from $0.018 \pm 0.01$ to $0.226 \pm 0.14 \mathrm{mg} / \mathrm{l}$ in POM season. Concentrations of iron in water samples of Kosi, Ramganga and Saryu River during PRM season exceeded the permissible limit i.e. $1 \mathrm{mg} / \mathrm{l}$, while water samples of Gola and Lohawati River exceeded the desirable limit i.e. $0.3 \mathrm{mg} / \mathrm{l}$. In POM season, water samples of all the rivers were found within limits but in earlier investigation, Kansal et al. (2013) also reported the higher iron concentration in river water samples of Uttarakhand.

Coliform group of bacteria are indicators of pathogenic organisms and the presence of coliform in water is an indicator of contamination of human or animal faecal waste. Human waste contamination in water causes waterborne diseases such as diarrhoea, typhoid and hepatitis (Theron and Cloete 2002; Elko et al. 2003; Sood et al. 2008). According to BIS, the coliform count should be $<10$ 
colonies/100 $\mathrm{ml}$ and absence of faecal coliform in water samples. During the analysis, average count of total coliform in water varied from $28 \pm 4.26$ to $105 \pm 11.51$ and from $25 \pm 1.48$ to $84 \pm 10.45$ colonies $/ 100 \mathrm{ml}$ and faecal coliform varied from $2 \pm 2.12$ to $23 \pm 4.97$ and from $2 \pm 1.48$ to $12 \pm 2.69$ colonies/100 $\mathrm{ml}$ in PRM and POM seasons, respectively. The analyzed data showed that water of all the rivers is contaminated with total and faecal coliform. High level of coliform counts in water samples indicates a contaminated source, inadequate treatments or post-treatment deficiencies and inadequate as well as unhygienic handling of solid waste.

\section{Correlation matrix}

The statistical analysis has been carried out by Pearson's correlation coefficient between different pairs of water quality parameters of river water to develop the significant correlation among the parameters (Bhandari and Nayal 2008; Joshi et al. 2009). The data analysis yielded an $\mathrm{R}$-value, which is a correlation representing the linear relationship between the data pairs. A linear association implies that as one variable increases, the other increases or decreases linearly. Values of the correlation coefficient close to +1 (positive correlation) imply that as one variable increases, the other increases nearly linearly. On the other hand, a correlation coefficient close to -1 implies that as one variable increases, the other decreases nearly linearly. Values close to 0 imply little linear correlation between the variables or no correlation (Mudgal et al. 2009). When data are truly independent, the correlation between data points is zero. The values of coefficient correlation were determined using SPSS software version13 in both PRM and POM seasons. Pearson's correlation in PRM and POM seasons showed strong positive and negative correlations among the parameters as shown in Table 2. The strong positive correlation of $\mathrm{pH}$ with $\mathrm{Mg}^{2+}$ in PRM $(r=0.901)$ and in POM $(r=0.915)$ is due to hydrolysis of ion on surface of water. Hardness showed strong positive correlations in both seasons of PRM and POM with alkalinity ( $r=0.901$ and 0.975$)$ and $\operatorname{TDS}(r=0.975$ and 0.948$)$ while hardness is also strong positive correlated with $\mathrm{Ca}^{2+}$ $(r=0.922)$. The result showed that there was great dependence of hardness on calcium, TDS, and alkalinity. The correlation analysis indicates that river water samples are hard. Alkalinity in PRM season strong positively correlated with TDS ( $r=0.964)$ and with $\mathrm{Mg}^{2+}$ in POM season $(r=0.901)$, TDS strong positive correlated with $\mathrm{Ca}^{2+}(r=0.909)$ during PRM season and $\mathrm{SO}_{4}{ }^{2-}$ negative correlated with $\mathrm{NO}_{3}{ }^{-}$ $(r=-0.892)$. The positive and negative correlation among the parameters could be taken as representing the major sources of seasonal changes in water quality.
Hydrochemical facies

The hydrochemical facies of river water can be obtained through Piper trilinear diagram (Piper 1994). This diagram effectively classifies the water quality by the distribution of major cations like $\mathrm{Na}^{+}, \mathrm{K}^{+}, \mathrm{Ca}^{2+}$ and $\mathrm{Mg}^{2+}$ and some major anions like $\mathrm{Cl}^{-}, \mathrm{SO}_{4}{ }^{2-} \mathrm{CO}_{3}{ }^{2-}$ and $\mathrm{HCO}_{3}{ }^{-}$. This diagram represents the cations and anions composition of samples on a single graph in which major groupings or trends in the data can be distinguish visually (Pradhan and Pirasteh 2011). It consists of geometrical combination of two outer triangles and a middle or inner diamond shaped quadrilateral. The distribution of major cations and anions in meq/l are shown by the left and right and these plotted points in the triangular fields are projected further into the central diamond-like quadrilateral structure, which provides the overall characteristics of the water samples.

In the present attempt, piper diagrams of water of all the rivers of Kumaun region of Uttarakhand during the PRM and POM seasons are presented in Fig. 2. The major ion chemistry results show that calcium is the dominant cation and bicarbonate is the major anion in all the rivers. The plots from the results revealed that in all the water, alkali earth metal elements $\left(\mathrm{Ca}^{2+}+\mathrm{Mg}^{2+}\right)$ are higher than alkali elements $\left(\mathrm{Na}^{+}+\mathrm{K}^{+}\right)$and weak acids $\left(\mathrm{CO}_{3}{ }^{2-}+\mathrm{HCO}_{3}{ }^{-}\right)$ are higher than strong acids $\left(\mathrm{Cl}^{-}+\mathrm{SO}_{4}{ }^{2-}\right)$. It showed that all the river water samples during the study fall in the field $\mathrm{Ca}-\mathrm{Mg}-\mathrm{HCO}_{3}$ type. The chemical composition of the study area is influenced by rainfall, climate, rock type, rock division and various human activities (Cruz and Amaral 2004).

Drinking and irrigation water quality analyses

\section{Drinking water quality analysis}

Water quality index provides inclusive interpretation of the quality of surface and ground water and its suitability for drinking purpose. The main purpose of WQI is to change the complex water quality data into understandable and usable information by which common people can know the status of water sources in a particular region (Akoteyon et al. 2011; Vasanthavigar et al. 2010; Balan et al. 2012). The weighted arithmetic index method is used in present case for calculation of WQI using 11 water quality characteristics namely, turbidity, $\mathrm{pH}$, total hardness, alkalinity, chloride, total dissolved solids, calcium, magnesium, sulphate, nitrate and iron, which showed maximum variations in seasons and also varied significantly at different sampling sites, using the following equation:

$\mathrm{WQI}=\sum W_{i} Q_{i} / \sum W_{i}$ 
Table 2 Pearson's correlation for different water quality parameters of rivers during PRM and POM seasons

\begin{tabular}{|c|c|c|c|c|c|c|c|c|c|c|c|c|}
\hline Parameter & Season & Turbidity & $\mathrm{pH}$ & Hardness & Alkalinity & $\mathrm{Cl}^{-}$ & TDS & $\mathrm{Ca}^{2+}$ & $\mathrm{Mg}^{2+}$ & $\mathrm{SO}_{4}^{2-}$ & $\mathrm{NO}_{3}^{-}$ & $\mathrm{Fe}^{2+}$ \\
\hline \multirow[t]{2}{*}{ Turbidity } & PRM & 1 & & & & & & & & & & \\
\hline & POM & 1 & & & & & & & & & & \\
\hline \multirow[t]{2}{*}{$\mathrm{pH}$} & PRM & 0.307 & 1 & & & & & & & & & \\
\hline & POM & 0.108 & 1 & & & & & & & & & \\
\hline \multirow[t]{2}{*}{ Hardness } & PRM & 0.243 & 0.581 & 1 & & & & & & & & \\
\hline & POM & -0.198 & 0.770 & 1 & & & & & & & & \\
\hline \multirow[t]{2}{*}{ Alkalinity } & PRM & -0.029 & 0.732 & 0.901 & 1 & & & & & & & \\
\hline & POM & -0.197 & 0.860 & 0.975 & 1 & & & & & & & \\
\hline \multirow[t]{2}{*}{$\mathrm{Cl}^{-}$} & PRM & -0.203 & 0.045 & -0.081 & -0.120 & 1 & & & & & & \\
\hline & POM & 0.147 & 0.753 & 0.457 & 0.481 & 1 & & & & & & \\
\hline \multirow[t]{2}{*}{ TDS } & PRM & 0.130 & 0.700 & 0.975 & 0.964 & -0.007 & 1 & & & & & \\
\hline & POM & -0.204 & 0.597 & 0.948 & 0.856 & 0.441 & 1 & & & & & \\
\hline \multirow[t]{2}{*}{$\mathrm{Ca}^{2+}$} & PRM & 0.495 & 0.767 & 0.922 & 0.853 & -0.223 & 0.909 & 1 & & & & \\
\hline & POM & 0.188 & 0.640 & 0.447 & 0.596 & 0.016 & 0.164 & 1 & & & & \\
\hline \multirow[t]{2}{*}{$\mathrm{Mg}^{2+}$} & PRM & 0.350 & 0.901 & 0.380 & 0.586 & -0.330 & 0.485 & 0.661 & 1 & & & \\
\hline & POM & -0.127 & 0.915 & 0.781 & 0.901 & 0.460 & 0.549 & 0.811 & 1 & & & \\
\hline \multirow[t]{2}{*}{$\mathrm{SO}_{4}{ }^{2-}$} & PRM & 0.841 & 0.586 & 0.647 & 0.398 & 0.091 & 0.581 & 0.783 & 0.419 & & & \\
\hline & POM & -0.160 & -0.258 & 0.129 & 0.117 & -0.805 & 0.066 & 0.424 & 0.077 & 1 & & \\
\hline \multirow[t]{2}{*}{$\mathrm{NO}_{3}{ }^{-}$} & PRM & -0.561 & -0.434 & -0.774 & -0.492 & -0.324 & -0.704 & -0.731 & -0.124 & -0.892 & 1 & \\
\hline & POM & -0.211 & 0.004 & 0.434 & 0.240 & 0.330 & 0.692 & -0.591 & -0.178 & -0.237 & 1 & \\
\hline \multirow[t]{2}{*}{$\mathrm{Fe}^{2+}$} & PRM & 0.050 & 0.164 & -0.501 & -0.426 & 0.725 & -0.391 & -0.379 & 0.029 & 0.037 & 0.051 & 1 \\
\hline & POM & -0.580 & 0.146 & 0.383 & 0.281 & 0.520 & 0.549 & -0.564 & 0.017 & -0.489 & 0.804 & 1 \\
\hline
\end{tabular}

Bold values signify correlation between ions at level 0.05 (two-tailed)

The unit weight $\left(W_{i}\right)$ for each water quality parameter is calculated using the following equation:

$W_{i}=K / S_{i}$

where, $K$ is appropriately constant and $S_{i}$ is the standard permissible value of the $i$ th parameter. The quality rating $\left(Q_{i}\right)$ of Eq. (1) is calculated as under.

$Q_{i}=\left(C_{i} / S_{i}\right) \times 100$

where, $C_{i}$ is estimated concentration of $i$ th parameter in the analyzed water. The standard rating of water quality according to WQI is given below in Table 3. The calculated WQI for water samples of all the five major rivers for determining their suitability for drinking purpose is given in Table 4.

The result showed that the higher value of WQI was found in PRM compared to POM season in river water. In PRM season the water qualities of all the rivers were found unsuitable with grade 'E' except as depicted in Fig. 3. In POM, the water quality of the rivers was found with good to unsuitable water quality with grade ' $B$ ' and ' $E$ '. The unsuitability of river water during PRM and POM seasons is mainly due to the high concentration of turbidity, iron and total coliform, which are recorded more than the permissible limit. The high water quality index is also contributed in river water by a large amount of anthropogenic activities nearby river banks such sewage discharge, cremation, detergents from bathing and clothes washing as well as agricultural runoff.

\section{Irrigation water quality analysis}

All the five rivers are also being used for irrigation purposes but none of the river water has so far been analyzed for suitability of irrigation purposes. In the view of the same, water of all the five rivers was also analyzed for their suitability and usefulness to meet the irrigational needs of farmers and local population of the area. The suitability of water for irrigation purposes has been evaluated through three parameters namely, SAR, sodium percent $(\mathrm{Na} \%)$ and RSC.

\section{Sodium adsorption ratio}

Sodium adsorption ratio is used to evaluate the excess of sodium with calcium and magnesium (Richards 1954). In general, the permeability of water reduces due to excessive sodium content in water. Use of water having high SAR level continuously can lead to the increase in Na level over the time, which in turn can adversely affect soil infiltration 
Fig. 2 Piper trilinear diagram for hydrochemical profile of five rivers during PRM and POM seasons

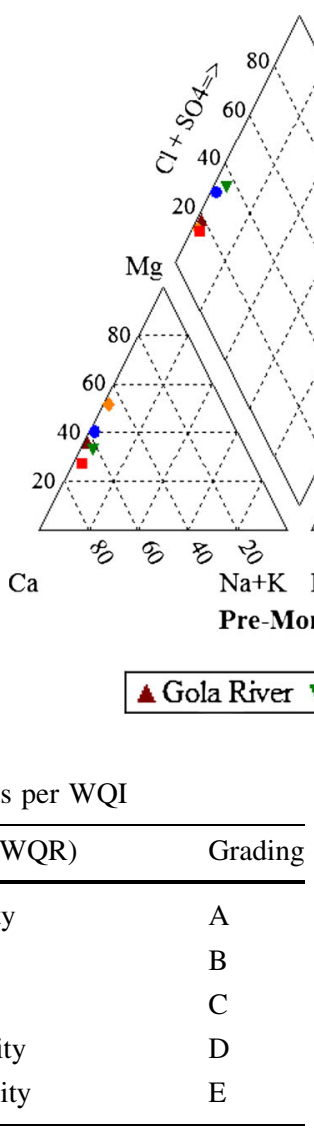

Table 3 Standard rating of water quality as per WQI

\begin{tabular}{lll}
\hline WQI scale & Water quality rating (WQR) & Grading \\
\hline $0-25$ & Excellent water quality & $\mathrm{A}$ \\
$26-50$ & Good water quality & $\mathrm{B}$ \\
$51-75$ & Poor water quality & $\mathrm{C}$ \\
$76-100$ & Very poor water quality & $\mathrm{D}$ \\
$>100$ & Unsuitable water quality & $\mathrm{E}$ \\
\hline
\end{tabular}

Table 4 Water quality index of the river water during PRM and POM seasons

\begin{tabular}{lrlrll}
\hline Name of rivers & \multicolumn{2}{l}{ PRM } & & \multicolumn{2}{l}{ POM } \\
\cline { 2 - 3 } \cline { 6 - 6 } \cline { 5 - 6 } & WQI & WQR & & WQI & WQR \\
\hline Gola River & 139.22 & Unsuitable & & 64.61 & Poor \\
Kosi River & 204.01 & Unsuitable & & 47.93 & Good \\
Ramganga River & 163.67 & Unsuitable & 59.37 & Poor \\
Saryu River & 177.36 & Unsuitable & 108.79 & Unsuitable \\
Lohawati River & 73.44 & Poor & 59.42 & Poor \\
\hline
\end{tabular}

and percolation rates. In addition to this, excessive SAR levels can also cause soil crusting, poor seedling and poor aeration (Lesch and Suarez 2009).

The following equation is used for the calculation of SAR values.

$\mathrm{SAR}=\frac{\mathrm{Na}^{+}}{\sqrt{\frac{\left(\mathrm{Ca}^{2+} \mathrm{Mg}^{2+}\right)}{2}}}$

where, all the concentrations of ions in meq/l. The SAR for all the river water is calculated using above equation and the results of SAR were found within the range 0.03-0.06 meq/l during PRM season and 0.05-0.08 meq/l in POM season. Based on classification (Richards 1954)

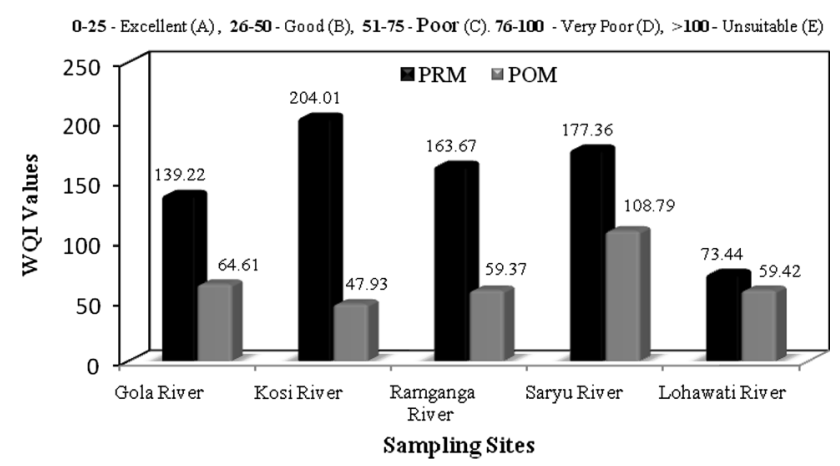

Fig. 3 Seasonal variation in WQI of all the five rivers during PRM and POM seasons

represented in Table 5, it is observed that water of all the five rivers were excellent for irrigation purposes.

\section{Residual sodium carbonate}

The sodium hazard also increases, if the water contains a higher concentration of bicarbonate ions. As the soil solution becomes more concentrated, there is tendency for calcium and magnesium to precipitate as carbonates, increasing thereby the relative proportion of sodium as a consequence. In present case, RSC was used to quantify effect of the carbonate and bicarbonate (Eaton 1950). RSC was calculated using the following equation:

$\mathrm{RSC}=\left(\mathrm{CO}_{3}^{2-}+\mathrm{HCO}_{3}^{-}\right)-\left(\mathrm{Ca}^{2+}+\mathrm{Mg}^{2+}\right)$

where, all ionic concentrations are measured in terms of meq/l. The calculated RSC values of all the rivers ranged from -0.69 to $1.20 \mathrm{meq} / \mathrm{l}$ in PRM season and from -0.27 to $1.02 \mathrm{meq} / \mathrm{l}$ in POM season. The classification of river water according to RSC value indicates that all obtained results of RSC were lower than $1.25 \mathrm{meq} / \mathrm{l}$ and fall under 
Table 5 Classification of river water for irrigation purposes based on SAR

\begin{tabular}{llll}
\hline SAR scale & Water class & PRM & POM \\
\hline $0-10$ & Excellent & All rivers & All rivers \\
$10-18$ & Good & - & - \\
$18-26$ & Fair & - & - \\
$>26$ & Poor & - & - \\
\hline
\end{tabular}

Table 6 Classification of river water for irrigation purposes based on RSC

\begin{tabular}{llll}
\hline SAR scale & Water class & PRM & POM \\
\hline$<1.25$ & Safe/good & All rivers & All rivers \\
$1.25-2.50$ & Marginal/doubtful & - & - \\
$>2.50$ & Unsuitable & - & - \\
\hline
\end{tabular}

Table 7 Classification of river water for irrigation purposes based on $\mathrm{Na} \%$

\begin{tabular}{llll}
\hline SAR scale & Water class & PRM & POM \\
\hline$<20$ & Excellent & All rivers & All rivers \\
$20-40$ & Good & & \\
$40-60$ & Permissible & - & - \\
$60-80$ & Doubtful & - & - \\
$>80$ & Unsuitable & - & - \\
\hline
\end{tabular}

the excellent category of water quality. Therefore, all river water was found suitable for irrigation purpose (Table 6).

\section{Sodium percentage}

Sodium percentage is an another parameter to evaluate water quality for irrigation purposes. Excess of sodium in water reacts with soil, reduces soil permeability and supports little or no plant growth (Wilcox 1955). The Na\% in water sample was calculated by following equation:

$\mathrm{Na} \%=\frac{\mathrm{Na}^{+}+\mathrm{K}^{+}}{\left(\mathrm{Ca}^{2+}+\mathrm{Mg}^{2+}+\mathrm{K}^{+}+\mathrm{Na}^{+}\right)} \times 100$

where, all the concentrations of ions are in meq/l. The $\mathrm{Na} \%$ in water ranged from 0.65 to $1.51 \mathrm{meq} / \mathrm{l}$ during PRM season and 1.22-2.75 meq/l during POM season. The calculated $\mathrm{Na} \%$ showed that water of all the rivers fall within the excellent water quality (Table 7) for irrigation needs.

\section{Conclusions}

The results of monitoring programme represent the first analysis of its type undertaken on all five Himalayan rivers system in Kumaun region of Uttarakhand to assess the quality of water for drinking and irrigation purposes. All the water quality parameters showed significant seasonal variation and recorded higher value in PRM compared to POM which indicates the effective ionic leaching, due to dilution. The analyzed result showed that the parameters namely, turbidity, TDS, alkalinity, hardness calcium and magnesium exceed the desirable limits but are within permissible limits, while the concentration of iron exceeded the desirable and permissible limits due to anthropogenic and geogenic activities. Higher contamination of total and faecal coliform in all the river water samples showed that river water is under contamination from sewerages and also through runoffs from the places of open defecation on the banks. Piper diagram revealed that all the river water samples of $\mathrm{Ca}-\mathrm{Mg}-\mathrm{HCO}_{3}$ type. Analysis of water quality for drinking purposes of all the rivers by means of water quality index also concluded that water was found unsuitable for drinking purpose, while found fit for irrigation purpose. The results highlighted that proper sanitary facilities should be provided in the area to control bacterial contamination in the rivers system, which is the most problematic issue. In addition to this, establishing the rain water harvesting and urban drainage systems in the area can minimize the diffusion of pollution from urban and agricultural runoff in river. There is also urgent need for formulation of strategies for maintaining water quality of all the five rivers of Uttarakhand, which are important assets of Himalayan region.

Acknowledgments Authors are thankful to the Uttarakhand State Council for Science \& Technology (UCOST), Dehradun and Uttarakhand Jal Sansthan (UJS), Dehradun for financial assistance provided for this work.

Open Access This article is distributed under the terms of the Creative Commons Attribution License which permits any use, distribution, and reproduction in any medium, provided the original author(s) and the source are credited.

\section{References}

Akoteyon IS, Omotayo AO, Soladoye O, Olaoye HO (2011) Determination of water quality index and suitability of urban river for municipal water supply in Lagos, Nigeria. Eur J Sci Res 54(2):263-271

Alam JB, Hossain A, Khan SK, Banik BK, Islam MR et al (2007a) Deterioration of water quality of Surma River. Environ Monit Assess 134:233-242

Alam MJB, Islam MR, Muyen Z, Mamun M, Islam S (2007b) Water quality parameters along rivers. Int $\mathrm{J}$ Environ Sci Technol 4(1): $159-167$

Baig AA, Mahmood Q, Nawab B, Hussain A, Nafees M (2010) Assessment of seasonal variation in surface water quality of Chitral River, North West Frontier Province (NWFP), Pakistan. World Appl Sci J 9(6):674-680 
Balan IN, Shivakumar M, Kumar PDM (2012) An assessment of groundwater quality using water quality index in Chennai Tamil Nadu India. Chron Young Sci 3(2):146-150

Bhandari NS, Joshi HK (2013) Quality of spring water for irrigation in the Almora district of Uttarakhand, India. Chin J Geochem 32:130-136

Bhandari NS, Nayal K (2008) Correlation study of physico-chemical parameters and quality assessment of Kosi River water, Uttarakhand. E-J Chem 5(2):342-346

Bu H, Tan X, Li S, Zhang Q (2010) Temporal and spatial variations of water quality in the Jinshui River of the South Qinling Mts., China. Ecotoxicol Environ Saf 73(5):907-913

Bureau of Indian Standards (BIS) (1991) Specifications for drinking water IS:10500:1991. Bureau of Indian Standards, New Delhi

Chandra R, Singh S, Raj A (2006) Seasonal bacteriological analysis of Gola river water contaminated with pulp paper mill waste in Uttaranchal, India. Environ Monit Assess 118:393-406

CPCB (2010) Status of water quality in India 2010. www.cpcb.nic.in/ WQSTATUS_REPORT2010.pdf

Cruz JV, Amaral CS (2004) Major ion chemistry of groundwater from perched-water bodies of the Azores (Portugal) volcanic archipelago. Appl Geochem 19:445-459

Desai J, Tank SK (2010) Deterioration of water quality due to immersion of Ganesh idols in the river Tapti at Surat (India). J Environ Res Dev 4(4):999-1007

Dorner SM, Anderson WB, Gaulin T, Candon HL, Slawson RM, Payment P, Huck PM (2007) Pathogen and indicator variability in a heavily impacted watershed. J Water Health 5(2):241-257

Eaton FM (1950) Significance of carbonates in irrigation waters. Soil Sci 69:123-133

Eaton AD, Clesceri LS, Rice EW, Greenberg AE (2005) Standard methods for the examination of water and waste water. American Public Health Association (APHA), Washington

Elko L, Rosenbach K, Sinnott J (2003) Cutaneous manifestation of waterborne infection. Curr Infect Dis Rep 5(5):398-406

Fordyce FM, Vrana K, Zhovinsky E, Povoroznuk V, Toth G, Hope BC, Iljinsky U, Baker J (2007) A health risk assessment for fluoride in Central Europe. Environ Geochem Health 29(2):83-102

Gupta VK, Dobhal R, Nayak A, Agarwal S, Uniyal DP, Singh P, Sharma B, Tyagi S, Singh R (2012a) Toxic metal ions in water and their prevalence in Uttarakhand, India. Water Sci Tech: Water Supply 12(6):773-782

Gupta VK, Nayak A, Agarwal S, Dobhal R, Singh P et al (2012b) Arsenic speciation analysis in and remediation technique in drinking water. Desalin Water Treat 40:231-243

Heizer WD, Sandler RS, Seal E, Murray SC, Busby MG, Schliebe BG, Pusek SN (1997) Intestinal effects of sulfate in drinking water on normal human subjects. Dig Dis Sci 42(5):1055-1061

Joshi DM, Bhandari NS, Kumar A, Agarwal N (2009) Statistical analysis of physico-chemical parameters of water of River Ganga in Haridwar district. Rasayan J Chem 2(3):579-587

Kansal A, Siddiqui NA, Gautam A (2013) Assessment of heavy metals and their interrelationships with some physicochemical parameters in eco-efficient rivers of Himalayan region. Environ Monit Assess 185(3):2553-2563

Knobeloch L, Salna B, Hogan A, Postle J, Anderson H (2000) Blue babies and nitrate contaminated well water. Environ Health Perspect 108(7):675-678

Kumar SK, Chandrasekar N, Seralathan P, Godson PS, Magesh NS (2012) Hydrogeochemical study of shallow carbonate aquifers, Rameswaram Island, India. Environ Monit Assess 184(7):4127-4138

Lesch SM, Suarez DL (2009) A short note on calculating the adjusted SAR Index. Am Soc Agric Biol Eng 52(2):493-496

McCarthy MF (2004) Should we restrict chloride rather than sodium? Med Hypotheses 63(1):138-148
Morris RD, Naumova EN, Levin R, Munasinghe RL (1996) Temporal variation in drinking water turbidity and diagnosed gastroenteritis in Milwaukee. Am J Public Health 86(2):237-239

Mudgal KD, Kumari M, Sharma DK (2009) Hydrochemical analysis of drinking water quality of Alwar district, Rajasthan. Nature Sci 7(2):30-39

Napacho ZA, Manyele SV (2010) Quality assessment of drinking water in Temeke district (part II): characterization of chemical parameters. Afri J Environ Sci Tech 4(11):775-789

Narasimha Rao C, Dorairaju SV, Bujagendra Raju M and Chalapathi PV (2011). Statistical analysis of drinking water quality and its impact on human health in Chandragiri, near Tirupati, India. www.eco-web.com/edi/111219.html

Nas B, Ali B (2006) Ground water contamination by nitrates in the city of Konya (Turkey): a GIS perspective. J Environ Manag 79(1):30-37

Paliwal PC, Sati SC (2009) Distribution of aquatic fungi in relation to physico-chemical factors of Kosi Rivers in Kumaun Himalaya. Nat Sci 7(3):70-74

Piper AM (1994) A graphic procedure in the geochemical interpretation of water analysis. Trans Am Geophys Union 25:914-928

Pradhan B, Pirasteh S (2011) Hydro-chemical analysis of the ground water of the Basaltic catchments: upper Bhatsai region, Maharashtra. Open Hydrol J 5:51-57

Rajappa B, Manjappa S, Puttaiah ET (2010) Monitoring of heavy metal concentration in groundwater of Hakinaka Taluk, India. Contem Eng Sci 4:183-190

Rani N, Sinha RK, Prasad K, Kedia DK (2011) Assessment of temporal variation in water quality of some important rivers in middle Gangetic plain, India. Environ Monit Assess 174:401-415

Rawat AS, Sah R (2009) Traditional knowledge of water in Kumaun Himalaya. Ind J Trad Knowl 8(2):249-254

Richards LA (1954) Diagnosis and improvement of saline and alkali soils. United States Department of Agriculture, Washington, DC

Sati SC, Paliwal PC (2008) Physico-chemical and bacteriological analysis of Kosi River water in central Himalaya. Pollut Res 27(1):179-183

Semwal N, Akolkar P (2006) Water quality assessment of scared Himalayan Rivers of Uttarakhand. Curr Sci 91(4):486-496

Semwal N, Jangwan JS (2009) Major ion chemistry of River Bhagirathi and River Kosi in Uttarakhand Himalaya. Int J Chem Sci 7(2):607-616

Seth R, Singh P, Mohan M, Singh R, Aswal RS (2013a) Monitoring of phenolic compounds and surfactant in water of Ganga, Haridwar (India). Appl Water Sci 3(4):717-720

Seth R, Singh P, Mohan M, Singh R, Gupta VK, Uniyal DP, Dobhal R, Gupta S (2013b) Assessment of water quality of Kosi Rivers, Almora, Uttarakhand (India) for drinking and irrigation purposes. Appl Chem Lett 3(4):287-297

Seth R, Mohan M, Dobhal R, Gupta VK, Singh P, Singh R, Gupta S (2014) Application of chemometric techniques in the assessment of groundwater quality of Udham Singh Nagar. Water Qual Expo Health, Uttarakhand. doi:10.1007/s12403-014-0127-5

Sharma D, Kansal A (2011) Water quality analysis of River Yamuna using water quality index in the national capital territory, India (2000-2009). Appl Water Sci 1:147-157

Sharma B, Tyagi S, Singh R, Singh P (2012) Monitoring of organochlorine pesticides in fresh water samples by gas chromatography and bioremediation approaches. Nat Acad Sci Lett 35(5):401-413

Shetty S, Tharavathy NC, Lobo RO, Shafakatullah N (2013) Seasonal variation in the physico-chemical characteristics along the upstream of Tungabhadra River, Western Ghats, India. Int J Plant Anim Environ Sci 3(1):242-246 
Shrivastava N, Mishra DD, Mishra PK, Bajpai A (2013) Water quality deterioration of Machna River due to sewage disposal, Betul, Madhya Pradesh, India. J Environ Earth Sci 3(6):1-5

Singh AK, Rawat DS (1985) Depletion of oak forest threatening springs: a exploratory survey. Nat Geogr J Ind 31(1):44-48

Sood A, Singh KD, Pandey P, Sharma S (2008) Assessment of bacterial indicators and physicochemical parameters to investigate pollution status of Gangetic River system of Uttarakhand (India). Ecol Indic 8(5):709-717

Theron J, Cloete TE (2002) Emerging waterborne infection: contributing factors, agent and detection tools. Crit Rev Microbiol 28(1): $1-26$

Trivedy RK, Goel PK (1986) Chemical and biological methods for water pollution studies. Environmental Publication, Karad
Tyagi S, Dobhal R, Kimothi PC, Adlakha LK, Singh P, Uniyal DP (2013) Studies of river water quality using river bank filtration in Uttarakhand, India. Water Qual Expo Health 5(3):139-148

Vasanthavigar M, Srinivasamoorthy K, Vijayaragavan K, Ganthi RR, Chidambaram S, Anandhan P, Manivannan R, Vasudevan S (2010) Application of water quality index for groundwater quality assessment: Thirumanimuttar sub-basin, Tamilnadu, India. Environ Monit Assess 171:595-609

WHO (2003) Sodium in drinking water: background document for preparation of WHO guidelines for drinking water quality. World Health Organization, Geneva

Wilcox LV (1955) Classification and use of irrigation waters. Circular number 969, United States Department of Agriculture Publication, Washington 